\title{
Heavy metal levels in paddy soils and rice from Ekiti Nigeria
}

\author{
A.S. OLATUNJI ${ }^{1}$, M.T ABDULLAH ${ }^{2 *}$
}

${ }^{1}$ University of Ibadan, Oyo State, Nigeria

(akinadeshadrach@yahoo.com)

${ }^{2}$ University of Ibadan, Oyo State, Nigeria

(*correspondence:mooktar.abdullah@gmail.com)

\section{Introduction}

According to recent research, a significant number of people across the world are exposed to heavy metals in rice. Rice is the world's most important cereal crop and also a bioaccumulator of heavy metals. Potentially toxic elements entered in the human body by any means affect the immune system, basic physiological processes of cell and gene expression and may cause nausea, anorexia, vomiting, gastrointestinal abnormalities, and dermatitis[1]

Twenty four soil and plant samples each were collected from Ekiti while seven rice grain samples were collected from markets within. Elemental analysis were determined on these samples using Inductively Coupled Plasma Mass Spectrometry (ICPMS).

\section{Discussion of Results}

Organic and Heavy Metals in Soils

The LOI indicates presence of organic content thereby aiding adsorption of heavy metals. Increase in the organic content of sediment may be accompanied by increase in chemical contaminants that co vary in relation to a common environmental factor (e.g. greater proportions of finer-grained sediment particles, which provide greater surface area for adsorption of both organic and other chemical pollutants) [2] Results revealed soil samples have mean $\mathrm{Co}, \mathrm{Ni}, \mathrm{Cu}, \mathrm{Zn}$, As, $\mathrm{Cd}, \mathrm{Pb}$ concentrations fall within the acceptable limits [3] for soil; $\mathrm{Cr}$ was observed to be above the acceptable limits[3] at some sampling points while for the plant samples showed $\mathrm{Cr}$, $\mathrm{Mn}, \mathrm{Ni}, \mathrm{Zn}, \mathrm{As}, \mathrm{Cd}, \mathrm{Pb}$ mean and median concentrations exceed acceptable limits [3]. Bioconcentration factor showed reavealed ease of uptake in order $\mathrm{Cd}>\mathrm{Zn}>\mathrm{Ni}>\mathrm{Pb}$. The result for rice revealed mean EDIs through the consumption of locally produced rice for $\mathrm{Cd}$ and $\mathrm{Pb}$ are 0.33 and $60.8 \%$ of the provisional tolerable daily intake values thereby posing $\mathrm{Pb}$ exposure risk.

[1] Tchounwou et al.(2012) EXS.2012;101:133-164. [2] Landrum et al.1990. LP:MI; 237-263. [3] World Health Organization (WHO). 2004. Cadmium. In: Safety evaluation of certain food additives and contaminants. Sixtyfirst meeting of the Joint FAO/WHO Expert Committee on Food Additives; Geneva (Switzerland): WHO Food Additives Series Number 52. 